\title{
MEMÓRIAS E NOTAS SOBRE PREGÕES E VENDEDORES DE RUA
}

ISSN: 1981-2434 Dourados - MS - Brasil

\section{MEMORIES AND NOTES ON CRIES AND STREET SELLERS}

MARIA ALICE RIBEIRO GABRIEL*

\begin{abstract}
RESUMO
O pequeno comerciante explora inúmeros recursos para vender um produto, como pregões, linguagem corporal, elementos parodísticos, poesia oral, cantos e sons ritmados, artifícios verbais, entonação de voz e linguagem estilizada. O objetivo do presente estudo é comentar descrições de vendedores ambulantes, cantos e pregões de rua como objetos culturais em textos memorialísticos. Considerando tal propósito, neste artigo o conceito de objeto cultural se define em comparação com a ideia de "formas de fazer", termo cunhado por Michel de Certeau (1980) no campo dos estudos culturais sobre a vida cotidiana. A análise indica que relatos históricos, literários e memorialísticos contêm dados relativos à vendedores de rua e pregões, evidenciando aspectos artísticos e sociais que os definem como objetos culturais.
\end{abstract}

PALAVRAS-CHAVE: Objeto cultural. Pregões. Vendedores de rua.

\begin{abstract}
The small merchant explores many resources to sell a product, such as auction chants, body language, elements of parody, oral poetry, rhythmic songs and chants, verbal artistry, voice intonation and stylized language. The aim of the presente study is to comment depictions of street sellers, their chants and street cries as cultural objects in memorialistic writings. Considering this purpose, in this article the concept of cultural object is employed by comparison with the idea of "ways of operating", term coined by Michel de Certeau (1980) within the field of cultural studies on everyday life. The analysis indicates that historical, literary and memorialistic accounts register significant data on street sellers and street cries, emphasizing artistic and social aspects that define them as cultural objects.
\end{abstract}

KEYWORDS: Cultural object. Street cries. Street sellers.

* Doutora em História Social pela Universidade de São Paulo. Pesquisadora do LEJ, Laboratório de Estudos Judaicos da Universidade Federal de Uberlândia. E-mail: rgabriel1935@gmail.com 
A expansão dos estudos culturais nas últimas décadas do século $X X$ ampliou o interesse da etnologia, história, literatura e sociologia contemporâneas por temas, questões e objetos de estudo até então pouco discutidos no âmbito acadêmico. A importância atribuída à noção de memória impulsionou esse processo, ocasionando focos de análise, conceitos e teorias partilhadas por várias áreas do conhecimento.

Pesquisas sobre a relação entre memória e sociedade aproximaram campos diversos do saber que, sob prismas específicos, analisaram dimensões econômicas, políticas e sociais da história do cotidiano. A este campo dos estudos culturais filiamse reflexões do historiador francês Michel de Certeau (1924-1986) sobre maneiras e "artes de fazer" que singularizam atividades praticadas pelo "homem comum" na vida diária, unindo aspectos laborais, recreativos e mesmo simbólicos em sua realização:

Por esse prisma, a "cultura popular" se apresenta diferentemente, assim como toda uma literatura chamada "popular": ela se formula essencialmente em "artes de fazer" isto ou aquilo, isto é, em consumos combinatórios e utilitários. Essas práticas colocam em jogo uma ratio "popular" uma maneira de pensar investida numa maneira de agir, uma arte de combinar indissociável de uma arte de utilizar. (CERTEAU, 2003, p. 42).

Em A invenção do cotidiano (1980), Certeau avaliou a relação entre a produção de "objetos sociais" e o uso cotidiano que a população faz destes objetos:

Muitos trabalhos (...) dedicam-se a estudar seja as representações seja os comportamentos de uma sociedade. Graças ao conhecimento desses objetos sociais, parece possível e necessário balizar o uso que deles fazem os grupos ou os indivíduos. (CERTEAU, 2003, p. 39).

Analisando tal relação, Certeau (2003, p. 41-42, grifo do autor) evidenciou aspectos simbólicos e sociais da representação de objetos culturais, associando-os a certa poética, que consiste em uma "arte" ou "maneira de fazer". "Essas maneiras de fazer constituem as mil práticas pelas quais usuários se reapropriam do espaço organizado pelas técnicas da produção sócio-cultural". Tais práticas encerram "[...] uma multiplicidade de 'táticas' articuladas sobre os 'detalhes' do cotidiano (...) pela criatividade dispersa, tática e bricoladora dos grupos ou dos indivíduos" anônimos. A partir dessa ótica, a natureza do objeto cultural encerraria práticas e "artes de fazer".

O conceito de objeto cultural é reconhecido e definido por diversas áreas das ciências humanas. A perspectiva adotada por Certeau relaciona processos criativos à noção de objeto cultural, sem excluir a relevância dos contextos sociopolíticos para se analisar a procedência e circulação dos objetos em uma sociedade de consumo.

Sobre a ideia de objeto cultural, Karin Knorr-Cetina (1983, p. 136, grifo da autora) afirmou que a realidade não é apenas interpretada, mas "manufaturada". Se, na construção do saber, afirmou a socióloga, a resultante do trabalho científico é o mundo conhecido, os objetos culturais surgem da manufatura do saber, a qual leva os homens a dividirem esse mundo assimilado pela linguagem e práticas humanas, domínios que Certeau conciliou ao criar uma teoria cultural sobre a vida cotidiana.

Pensando os pregões de vendedores de rua na acepção de objetos culturais que reúnem aspectos específicos da linguagem, artes, maneiras e práticas de fazer, 
a justificativa da pesquisa que resultou neste artigo remete à escassez de estudos no país, nas últimas décadas, sobre esse tema, comum à história social, literatura e memorialística, conforme atestam os estudos de Christiane Reis Dias Villela Assano (2003), Walter Gracia (2013) e Luís Antônio Contatori Romano (2020a; 2020b).

Pregões e vendedores de rua estão desaparecendo do cotidiano das cidades, quase sem registro algum, em parte, devido às transformações econômicas e sociais que modificam usos e aspectos laborais do espaço onde se manifestam. Segundo o geógrafo Kevin Hetherington (2010, p. 15), quando um local associado a patrimônios culturais históricos é descaracterizado devido a políticas de expansão urbana, vestígios arqueológicos representativos da memória daquele espaço podem ser encaminhados a coleções particulares, fundações e museus. Com o impacto da crise econômica em fins da primeira década do século XXI sobre essas instituições dedicadas a interpretar o passado, investimentos públicos e privados destinados às artes e setor patrimonial diminuíram em muitos países. Tal fato pressupõe o extravio de objetos culturais que poderiam ser conservados e incluídos na vida cultural do presente e do futuro, na acepção de uma herança narrativa no tempo e no espaço.

Certeau (1998, p. 138) faz uma crítica à lógica existente nessa conservação. Ainda que distribuídos fora dos templos patrimoniais e à disposição dos habitantes, objetos restaurados se tornam peças de museu, do qual ampliam o domínio quando disseminados, museificando áreas da cidade. Esta função de planejamento urbano do museu tem regras próprias, e permite ao observador e usuário atribuírem sentido diverso ao mesmo objeto cultural. De teor científico, didático e teatral, a operação que distancia os objetos de seu sentido cotidiano (pretérito ou atual) justifica-se por ensejar a curiosidade, informação ou análise. Logo, o museu força objetos culturais a se moverem de um sistema de práticas a outro. Orientado ao planejamento urbano, o aparato produz a substituição de destinatários: retira de moradores usuais edifícios que, por meio de uma renovação, destina a outros usos e clientela. A questão envolve não só espaços e objetos renovados, mas os beneficiários da renovação. A mobilidade de um sistema de práticas vinculado a certo objeto cultural é um fenômeno histórico que tem sido investigado por antropólogos e historiadores.

Legados pela tradição, episódios da história do cotidiano podem tornar-se símbolo identitário coletivo, patrimônio material e imaterial. Em History and Popular Memory (2014), o historiador Paul Cohen avaliou o complexo fenômeno do "apelo" que a imagem de Joana d'Arc exerceu durante a Segunda Guerra sobre a população da França, incluindo líderes nacionais como Charles de Gaulle e Phillipe Pétain. A história da "Donzela de Orléans" comunicou a republicanos, socialistas, monarquistas e conservadores o espírito da nação francesa, associando-o às ideias de anglofobia, resistência ao invasor estrangeiro, fé absoluta em Deus, apelo à modéstia, inocência, piedade e santidade, coragem no campo de batalha e em face da morte, rebelião contra a autoridade e subversão de convenções sociais. Sistemas culturais tornam eventos e fenômenos sociais em objetos culturais, com significado específico para cada cultura, afirmou a socióloga Wendy Griswold (2013, p. 105). 
Para Cohen (2014, p. 9), em certas conjunturas, o significado de narrativas inscritas no passado de um país atualiza-se para servir de metáfora ao presente, circulando reformulado pela cultura popular, literatura e política. Assim, a Batalha de Kosovo de 1389 foi crucial para o nacionalismo sérvio no século XIX; a queda de Massada, no século I, tornou-se símbolo da moderna memória judaica; e a história do rei Goujian, fator de unificação da política nacionalista chinesa de Chiang Kai-Chek. O valor regional ou nacional dos objetos culturais é permeável ao imaginário popular e ajustado à memória coletiva por meio de artefatos, canções, discursos políticos, filmes, imagens, monumentos, poemas, propagandas e narrativas cujas dimensões histórica e simbólica acompanham as exigências sociais do momento.

Ao enfatizar a mobilidade cultural do mundo contemporâneo, Ivete Lara Camargos Walty (2011, p. 79-80) cita Walter Moser (2004), que abordou tal questão considerando a transferência de objetos culturais de um sistema a outro em contextos históricos concretos, transferência verificada nos deslocamentos geográficos e midiáticos, cujas operações transpõem as fronteiras do espaço por meio de permutas entre os suportes e tecnologias informativas no mecanismo de produção artística. Tal processo gera redes, conectando produtos culturais de origem diversa, que se instalam na sociedade por um mecanismo transcultural marcado por movimentos de intersecção. Nas pequenas e grandes cidades, essa mobilidade cultural é visível na arquitetura, nos espetáculos apresentados nas ruas e nos espaços fechados, em manifestações comerciais, religiosas e políticas e, sobretudo, na circulação de pessoas com hábitos e linguagens diferentes. Existe, porém, outro tipo de circulação, aquela das pessoas esquecidas, que percorrem as ruas para garantir sua subsistência, exibindo, paradoxalmente, a impossibilidade de acesso a bens materiais e simbólicos, situação na qual é possível incluir os objetos de análise deste estudo: o vendedor de rua ambulante e os pregões. Embora não estejam extintos no século XXI, como observou Walter Garcia, deve-se notar que:

\begin{abstract}
Apesar de todas essas permanências, Gilberto Freyre, no princípio da década de 1960, lamentava o declínio dos pregões no Recife - alguns, perdidos porque não havia mais vendedores de, por exemplo, mel de engenho, sabão da costa ou alfenim; outros, "porque a venda que eles anunciavam tornou-se melancolicamente silenciosa na capital de Pernambuco. Abafados pelas buzinas dos automóveis e dos alto-falantes: duas pragas terríveis. Dois inimigos de morte dos pregões vindos dos velhos tempos coloniais". (FREYRE, 1961, p. 178-181 apud GARCIA, 2013, p. 21).
\end{abstract}

Sob novos enfoques de análise social, que conciliaram a história individual à dos objetos culturais, o estudo da cultura material expandiu-se no final do século XX. Para Chris Gosden e Yvonne Marshall (1999), o gênero memorialístico serve de paradigma à compreensão dessa ideia: sujeitos à influência do espaço e do tempo, indivíduos e objetos sofrem transformações sucessivas, o que permite seu estudo como entidades versáteis, aptas a refletir alterações na história econômica e social.

Apoiando-se nesta ponderação, este estudo pretende comentar descrições de vendedores ambulantes e pregões de rua, na acepção de objetos culturais, entre os séculos XIX e XX. O recorte espacial da pesquisa apreende cidades como Rio de Janeiro, Recife, Juiz de Fora e São Paulo, segundo o registro de Jean-Baptiste 
Debret, Gilberto Freyre, Mário Souto Maior, Pedro Nava e Jorge Americano, fontes que compreendem dados sócio-históricos e relatos memorialísticos. O objetivo é analisar comparativamente tais objetos culturais considerando-se as noções teóricas de artes e "práticas de fazer", desenvolvidas por Certeau (1980), mas observando também noções concernentes à representação do passado pela memória pessoal tornada arquivo da memória social, tal como a noção de "traços", descrita a seguir.

\title{
Traços históricos dos pregões
}

Herança comunitária, objetos culturais são acervos da memória local contendo vestígios ou traços do passado. Jean-Yves Boursier (2002) definiu como "traços" do passado sobrevivências, vestígios e ruínas que testemunham sobre uma atividade humana, clima, cultura, evento ou filiação, sendo interessantes ao homem, por materializarem algo já desaparecido, fornecendo-lhe uma representação para estudo, comemoração e recordação, imagem que será posicionada em um sistema de evolução cronológico. O interesse por vestígios do passado justifica pesquisas e operações museológicas que transformam objetos em relíquias, rastreando suas origens e conexões à procura de traços representativos de uma filiação ou território.

Nesse sentido, a história dos pregões alude à função social do vendedor ambulante, cingida principalmente à escravidão no Brasil colonial. Historiadores, cronistas e viajantes descreveram "traços", usos e costumes de diferentes espaços e épocas, fontes das quais se infere que objetos culturais têm ligações exclusivas com transformações no ambiente. Atinente ao pregão, o comentário de Marlos de Barros Pessoa sobre o advento e influência da imprensa em Recife ilustraria esse processo:

\begin{abstract}
[...] a mais intensa circulação da palavra escrita altera significativamente os padrões de uma sociedade voltada para o rural, onde a oralidade tinha papel preponderante e onde a partir de então se promovem ideias de língua escrita para maiores setores da população. (...) em 1821, com a Aurora Pernambucana, primeiro jornal ali publicado, começa uma fase efetiva e crescente do papel da imprensa na vida da sociedade. O jornal ampliou a possibilidade de contato de largas faixas da população com a língua escrita, o que antes só era feito praticamente através de cartas, com todas as dificuldades que os correios da época apresentavam. Os anúncios publicados então refletem o acesso que as populações analfabetas e semi-analfabetas passam ter ao jornal, seja escrevendo como podiam, seja ditando para que outras pessoas escrevessem, seja reproduzindo os pregões de escravos na venda de variados produtos. (PESSOA, 2003, p. 94).
\end{abstract}

No entanto, junto ao reconhecimento dos vestígios culturais objetivos que um pregão pode evocar, tais como: avanços tecnológicos, letramento, regionalismos, movimentos migratórios e relações laborais, sua composição e expressão denotam, simultaneamente, critérios subjetivos ligados à memória e história pessoal de gente simples, quase sempre anônima, conforme observou Maria Elisa Collier Pragana:

O que é pregão? O verbo a que se junta o substantivos nos dicionários é pregar. $\mathrm{O}$ pregar dos pregadores. O pregar dos sermões. O pregar dos que proclamam altas virtudes de santos ou de ideias ou de nações. Daí o "que 
não é prêmio vil ser conhecido, por um pregão do ninho meu paterno" de Camões. Mas esse ato de pregar pode ser o de simples e bons. (PRAGANA, 1988, p. 127).

Na esfera social, Viagem pitoresca e histórica ao Brasil (1834-1839) sugere quais iguarias ofertadas nas ruas do Rio de Janeiro durante o verão atraíram o olhar do viajante Jean-Baptiste Debret. Compare-se o excerto às descrições do folclorista Mário Souto Maior e às do memorialista Pedro Nava sobre a venda de roletes de cana-de-açúcar e outros produtos, respectivamente, em Recife e no Rio de Janeiro, no início do século XX. Além do registro dos costumes, similar ao de Debret, ambos enfatizam o aspecto mnemônico dos pregões, por meio da "melodia" e da "saudade":

Figura 01: "Os refrescos da tarde no Largo do Palácio" (1826), de Jean-Baptiste Debret.

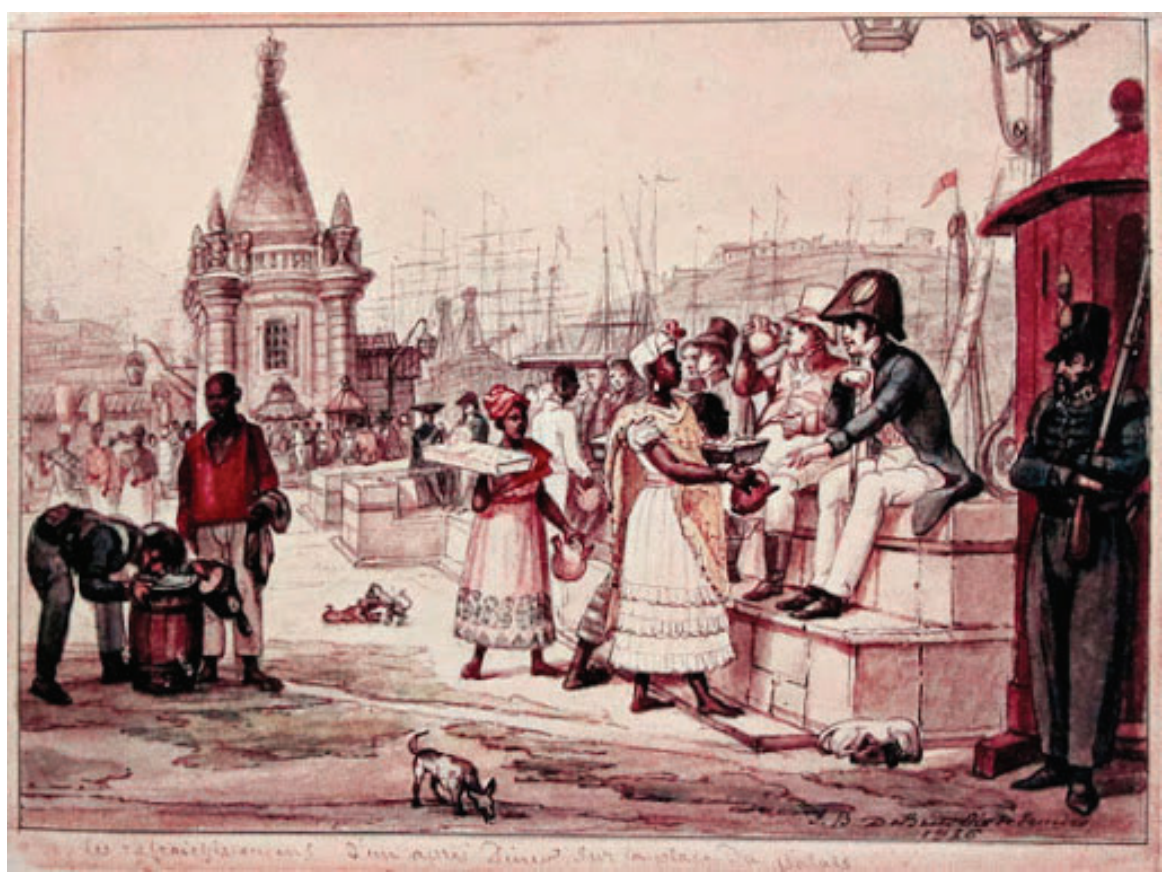

FONTE: Gravura de Viagem Pitoresca e Histórica ao Brasil (1834)1

Esse sistema consiste em cortar a cana em pequenos pedaços do comprimento do intervalo entre dois nós; raspados em seguida, e inteiramente limpos de sua casca fibrosa, são mergulhados n'água fresca e amarrados em pequenos feixes de sete ou oito pedaços, que se conservam debaixo de uma toalha molhada e são vendidos a dez réis cada um. Esses pequenos pedaços, de um verde esbranquiçado e transparente, convidam o transeunte a desalterarse, pois a cada dentada enchem-lhe a boca de um suco abundante, inodoro e muito doce. (...) O xarope de orchata é também muito usado e é feito com a amêndoa da semente de melancia, que substitui, em geral, no Rio de Janeiro, o fruto da amendoeira, a qual não é cultivada no Brasil. Recorre-se também ao miolo refrescante de certas frutas de verão, como a melancia, a pitanga, a jabuticaba, o araçá e a polpa de tamarindo, etc. Em princípios de Março, o número dessas vendedoras improvisadas diminui sensivelmente, ficando entregue às quitandeiras a venda da cana de açúcar, durante o resto

1 Imagem retirada pela autora do site MultiRio: História do Brasil. Disponível em: <http://multirio. rio.ri.gov.br/index.php/estude/historia-do-brasil/rio-de-janeiro/52-o-rio-de-janeiro-como-a-capital-doreino/2476-a-cidade-do-rio-de-portas-abertas>. Acesso em: 03 de outubro de 2019. 
do ano. Mas à voga das substâncias refrescantes sucede então o amor às guloseimas, mantido em apetite, sucessivamente, pelas vendedoras de manuê, de pastéis quentes, de sonhos, doces, etc., muito diferentes dos da Bahia. O manuê é um folhado recheado de carne, bastante suculento e bom para se comer quente; por isso a vendedor de manuê tem o cuidado de cobrir sempre o tabuleiro com uma toalha e uma coberta de lã. (DEBRET, 1954, p. 218, grifo do autor).

Os pregões são outra manifestação folclórica de muita beleza. Cantados, falados, ou tocados, cada cidade tem os seus pregões. E o Recife, como não poderia deixar de ser, também tem os seus. Entre os pregões antigos temos o do vendedor de pitomba: "- Ei, piripiripiripiripitomba! Menino chora prá comprar pitomba! Ei, pitomba!" Outros pregões enchem de melodia a vida e a saudade de muita gente: "- Olhe o rolete! Rolete é de cana caiana! Quem vai querer?”; (...) "- Ostra chegada agora! Chegada agora... Chegada agora...”; "-Mé novo, de engenho!”; (...) “- Macaxeira! Macaxeira Bahia, cozinha n’água fria!" (...) E estes outros, também bonitos e saudosos, como: "- Doce gelado!" “- Sorvete! É de coco e de maracujá!" É bom explicar que doce gelado era como se denominava o picolé de hoje, logo quando apareceu. Era redondo e não tinha o formato dos picolés de agora. Os pregões atuais, quase todos, com exceção de alguns, são tocados como a trombeta do vendedor de picolé, a sineta do pipoqueiro, a gaitinha do vendedor de cuscuz e do amolador de tesouras, a sineta do caminhão de gás, etc. Entre as exceções, lembro: "Olha o amendoim! Amendoim torradinho! "- Caranguejo! Olha o carangueijo!" (...) "- Cavala! Olha a cioba!" (MAIOR, s/d).

Mas já acabava o domingo, nas ruas escurecidas, que o gás de iluminação ia fazer virar num mundo verde e submarino. As visitas saíam uma por uma, demandando suas ruas da zona norte, onde havia restos de dobrados das retretas dominicais, farrapos de bandeiras de papel de seda, como numa permanente festa junina e vendedores dos roletes de cana passados num barbante. Iam e vinham cantando. Óoooooolha a cana, cana doce. Os parentes iam sendo levados procissionalmente ao portão. (NAVA, 1974, p. 334-335, grifo do autor).

No plano econômico, Debret observou que a jornada de trabalho do vendedor ambulante começava cedo, tão logo o canhão anunciava a abertura dos portos, às cinco e meia da manhã, com escravos transportando água, leite e mantimentos para a primeira refeição do dia. Esse comércio seguia abastecendo a população também no período noturno, por meio de "um movimento generalizado de quitandeiras":

De 6 a 7 horas encaminham-se sossegadamente para o centro da cidade os negros de ganho; uns preparam durante o caminho folhas para a confecção de chapéus (...) Às sete horas o canhão anuncia o fechamento dos portos e o seu troar junta-se ao toque da Ave-Maria. De 7 às 10 ouve-se nas ruas o pregão dos vendedores de amendoim torrado, de milho assado, pastéis quentes, pastéis de palmito, pudim quente, manuê, etc., iguarias de grande procura. (DEBRET, 1954, p. 288, grifo do autor).

A maior parte do comércio de vendedores ambulantes era sustentada pela mão de obra do chamado escravo de ganho. Nesse contexto, Luiz Carlos Soares 
(2007, p. 68) citou o relato do viajante norte-americano Thomas Ewbank, entre 1845 e 1846, aludindo ao "horror" que os brasileiros brancos demonstravam socialmente pelo trabalho braçal, mesmo entre as camadas livres pobres, a exemplo do jovem de 18 anos, empregado de um estabelecimento comercial no centro do Rio de Janeiro que, incumbido de levar a uma firma vizinha um pacote "[...] pouco maior que uma carta (...) chamou um negro, que atrás dele levou o pacote ao destinatário".

Sobre o comércio dos vendedores ambulantes, Mary C. Karasch (1987, p. 71) abordou a influência de um costume relativo à condição feminina em sociedades urbanas e agrárias até meados do século XIX: a mulher não podia ultrapassar os limites do domus e tampouco possuir ocupação remunerada. Somente mulheres de baixa extração social trabalhavam fora de casa. Entretanto, "não foram raras", como assinalou Gilberto Freyre (1996, p. 95), "avós quase rainhas", senhoras de engenhos e "fazendas quase do tamanho de reinos", donas de escravos de eito e de ganho. "Viúvas que conservaram e às vezes desenvolveram grandes riquezas. Quase matriarcas que tiveram seus capangas, mandaram dar suas surras, foram 'conservadoras' ou 'liberais' no tempo do Império", sinhás "de feitio amazônico", enérgicas, que administravam grandes propriedades, "[...] lidando com os vaqueiros, com os mestres-de-açúcar, com os cambiteiros, dando ordens aos negros”. Outras avós, matriarcas e viúvas teriam o patrimônio respaldado por escravos de ganho.

\section{Traços memorialísticos dos pregões}

Gilberto Freyre (1996, p. 95) citou um episódio registrado nas décadas iniciais do século XIX pelo barão expedicionário Georg Heinrich von Langsdorff, em visita a certa fazenda no Mato Grosso, "onde o homem da casa era uma mulher", matrona na faixa dos cinquenta anos, que "[...] andava entretanto por toda parte, a pé ou a cavalo, dando ordens aos homens com sua voz dominadora, dirigindo o engenho, as plantações, o gado, os escravos". Dada a sua constância nos registros históricos, o trabalho do escravo de ganho contribuía para a economia de muitas casas e não era privilégio da administração de sinhás, prossegue Gilberto Freyre (1996, p. 95): "[...] capazes de exercer o mando patriarcal quase com o mesmo vigor dos homens. Às vezes com maior energia do que os maridos já mortos ou ainda vivos, porém dominados, excepcionalmente, por elas". Em Baú de ossos (1972), de Pedro Nava, alguns exemplos biográficos aproximam-se da descrição apresentada em Sobrados e Mucambos (1936). O primeiro retrato alude à bisavó materna do memorialista:

Se quase não ficou lembrança do Capitão José Luís Pinto Coelho da Cunha, pai de Luís da Cunha - de sua mãe, a matriarca Dona Lourença Maria de Abreu e Melo, transmitiram-se várias reminiscências. Sua forte personalidade é presença nos seus descendentes (...) E se o som resulta do instrumento e a voz do físico - é pela palavra autoritária, estridente e peremptória da neta, que ouço o timbre da que vibrou em Mariana, em Santa Bárbara, no Caminho Novo e na fazenda de São Mateus. (...) Vinda à luz a 10 de agosto de 1781. (...) casou-se a 13 de novembro de 1796 com o Capitão José Luís Pinto Coelho da Cunha (...) levava sua vida autoritária de senhora dona de minas que forneciam ouro às pás para seus luxos de matrona. Um destes era 
o de ter sempre, em torno dela, doze escravas (...) Doze escravas tão claras quanto possível, cada qual mais peregrina, da mesma idade, do mesmo tipo, da mesma altura, do mesmo corpo e todas de dentes absolutamente perfeitos. (...) Os casamentos das filhas e dos filhos eram todos escolhidos por ela. (NAVA, 1974, p. 154-163).

Famílias abastadas expunham socialmente a fortuna de sua casa não só pela quantidade de escravos que possuíam, mas pela riqueza ostentada por meio deles. Os escravos tornavam-se símbolo extensivo do prestígio e prosperidade dos donos (KARASCH, 1987, p. 211). Relata o memorialista que as mucamas de D. Lourença,

[...] vestiam-se com roupas iguaizinhas às da dona. De rosa se ela estava de rosa. De azul se ela estava de azul. Amarelo, se de amarelo, verde se de verde (...) Depois, de negro e roxo, quando a viúva se cobriu de negro e roxo. As mesmas rendas, os mesmos veludos, as mesmas sedas, os mesmos vidrilhos, as mesmas fitas - só que o balão das mulatas não tinha vestígio de cauda, era antes curto, deixando ver um pouco das pernas morenas e dos pés descalços. Vê lá se D. Lourença admitia negro calçado... Tampouco usando joias e cheiros que nem a sinhá. (NAVA, 1974, p. 157).

Já Debret (1954, p. 217, ênfase do autor), comentando as "[...] substâncias refrescantes, indispensáveis durante os meses de Setembro, Janeiro e Fevereiro (...) vendidas nas ruas da capital por uma multidão de vendedores em sua maioria escravas de pequenos capitalistas ou por negras livres", observa que, dentre essas, "[...] as vendedoras de alvá são notáveis pela elegância ou ao menos, pela limpeza de seus trajes, naturalmente proporcionais à fortuna dos senhores, sempre interessados em conseguir, assim, alguma vantagem na concorrência momentânea".

O segundo retrato feminino das Memórias em uníssono com a referência de Gilberto Freyre (1996, p. 95) às matriarcas, "ilustres pelo sangue e mais poderosas pelo prestígio da fortuna como mais enérgicas pela ação," é o que se refere à Dona Maria Luísa, avó materna de Pedro Nava (1974, p. 17) e neta de Dona Lourença Maria de Abreu e Melo. De mentalidade "rural, escravocrata, dominadora e violenta", a "mineira da gema, D. Maria Luísa da Cunha Pinto Coelho Jaguaribe" tivera uma "vida de novela" no primeiro casamento. Contudo, após as segundas núpcias,

[...] envelhecendo de raiva e despeito, levava vida heroica em Juiz de Fora. Dotada de faro incomum para os negócios, econômica até a avareza, com o pouco que recebia do marido voador construiu os barracões e casinhas da Serra, nos terrenos que tinham ficado, perto da Academia de Comércio. Com os aluguéis desses próprios ressarciu, indenizou, compensou e (...) estava senhora do 177 e do 179 da Rua Direita, de seis casas na Serra (fora os barracões), de outra na rua Dr. Paletta, de outra na rua Santo Antônio, de outra em Belo Horizonte à esquina de Januária e Pouso Alegre. (NAVA, 1977, p. 20).

Em 1893, D. Maria Luísa e o segundo marido, Joaquim Nogueira Jaguaribe, adquirem a Fazenda do Bom Jesus, na Estação de Cotegipe, junto ao rio Paraibuna, que Pedro Nava (1974, p. 203-205) define, a partir das recordações de sua mãe e tias, como: "Paraíso terrestre, ilha da utopia, Pasárgada (...) de uma Inhá Luísa gritando ordens no seu Trianon", local onde: "Vendiam-se crias, bezerros, cabritos, leite, milho, fubá, café, cachaça, queijos, rapadura". No comércio dos artefatos da 
indústria doméstica, conforme sugerido neste excerto, possivelmente as funções do escravo de ganho e do vendedor ambulante seriam transferidas, no caso da família materna de Pedro Nava (1974, p. 259) a criados e "crias da casa", remanescentes da escravidão: "Abolida esta e não se podendo mais comprar o negro, as senhoras de Minas tomavam para criar negrinhas e mulatinhas sem pai e sem mãe ou dadas pelos pais e pelas mães2 (...) Em casa de minha avó materna funcionava o sistema", recordado por testemunhos orais e fonte escrita: "Minha avó escriturava. É pelo seu livro que sabemos os nomes das molecas suas crias, das criadas, dos camaradas e até das vacas". Que pregão teria anunciado as iguarias da cozinha da "Inhá Luísa"?

Cozinha de bons jantares, de bons almoços, onde minha avó fabricava litros de café-com-leite-de-açúcar-queimado, que mandava vender na Estação de Cotegipe. Os viajantes já vinham pendurados nas janelas do trem, e gritando pelas xícaras de ágate que lhes queimavam os beiços. Pelo bolo de fubá, solto e todo dourado que se esfarelava nos guarda-pós. (NAVA, 1974, p. 204).

De acordo com o censo de 1834, realizado na capital do Império, seis pardas e oitenta e uma mulheres brancas eram proprietárias de escravos, enquanto outras cinco eram negociantes e três eram donas de botequins. $O$ trabalho da mulher geralmente envolvia ocupações de menor prestígio social. A maioria das mulheres livres "de cor" trabalhava como vendedora de rua (234) ou criada (95). Poucas mulheres brancas eram vendedoras de rua (15), apenas algumas eram criadas (64). Surpreendentemente, a maioria (110) vinculava-se ao setor artesanal e outras $(23,026)$ estavam sem emprego (KARASCH, 1987, p. 71). Apesar da Abolição, a condição social do escravo de ganho não mudou significativamente de 1834 a 1893:

\begin{abstract}
O comércio ambulante do Rio de Janeiro apresentava uma grande variedade e quase todas as mercadorias eram vendidas por escravos de ganho pelas ruas da cidade, existindo ainda aqueles cativos que ficavam com seus cestos, tabuleiros ou em pequenas barracas improvisadas pelas praças, praias e portas de igreja. O Reverendo Kidder dizia que, para esse serviço, geralmente eram "escolhidos os escravos mais espertos e de melhor aparência, de ambos os sexos" e não era raro que esses cativos revelassem um "grande tato e tino comercial". Os vendedores ambulantes, principalmente aqueles que percorriam as ruas da cidade oferecendo seus produtos, procurando atrair os possíveis compradores com altos e sonoros pregões, que misturavam o canto com palavras, anunciando a excelência dos artigos que vendiam. (...) Os produtos vendidos eram verduras, flores, frutas, raízes comestíveis, legumes, aves, ovos, bolos, tortas, roscas, doces, presunto, carne, panelas, moringas, talheres, copos, pratos, roupas, sapatos, bonés enfeitados, joias de fantasia, livros e até mesmo peças de vidro, porcelana e prata. (SOARES, 2007, p. 125-126).
\end{abstract}

Atribuir ao pregão valor de objeto cultural requer ponderar sobre a questão da memória. Pierre Nora (1989, p. 7) arguiu que o presente converte-se velozmente em passado histórico e a percepção de que algo (ou tudo) venha a desaparecer com o passar do tempo indica uma ruptura de equilíbrio. Resquícios da experiência podem 2 Uma das crianças referidas por Pedro Nava (1977, p. 4) como "cria da casa" da avó materna foi Evangelina Berta, "A Catita, essa, era menina. Iria pelos seus sete anos e regulava com meu irmão José. (...) A Catita fora posta pela mãe, dormindo, num trilho da Piau. Fica quieta, bem. Quietinha, fecha o olho, dorme, que já volto. Mas o diabinho acordou, levantou, saiu e ainda foi jogado contra o barranco pelo vento da locomotiva que passava bufando. Vieram entregá-la em nossa casa". 
continuar a viver na tradição, no silêncio de um costume, na repetição do ancestral. Pedro Nava esboça ideia similar em Baú de ossos, destacando a noção de tradição:

\begin{abstract}
A memória dos que envelhecem (e que transmite aos filhos, aos sobrinhos, aos netos, a lembrança dos pequenos fatos que tecem a vida de cada indivíduo e do grupo com que ele estabelece contatos, correlações, aproximações, antagonismos, afeições, repulsas e ódios) é o elemento básico na construção da tradição familiar. Esse folclore jorra e vai vivendo do contato do moço com o velho - porque só este sabe que existiu em determinada ocasião o indivíduo cujo conhecimento pessoal não valia nada, mas cuja evocação é uma esmagadora oportunidade poética. Só o velho sabe daquele vizinho de sua avó, há muito coisa mineral dos cemitérios, sem lembrança nos outros e sem rastro na terra - mas que ele pode suscitar de repente (como o mágico que abre a caixa dos mistérios ) na cor dos bigodes, no corte do paletó, na morrinha do fumo, no ranger das botinas de elástico, no andar, no pigarro, no jeito - para o menino que está escutando e vai prolongar por mais cinquenta, mais sessenta anos a lembrança que the chega, não como coisa morta, mas viva qual flor toda olorosa e colorida, límpida e nítida e flagrante como um fato presente. (NAVA, 1974, p. 17).
\end{abstract}

Uma expressão atual de interesse pelo passado, ponderou Boursier (2002), traduz-se nas investigações genealógicas e pesquisas em acervos familiares que possam testemunhar sobre um enraizamento espacial em certo período, no qual a população seria mais itinerante e urbanizada. A tendência atual de patrimonialização (que reivindica a triagem de vestígios para selecionar quais seriam conservados ou descartados) exprime a nostalgia de um mundo perdido. Ao conciliar as ideias de traço, luto e herança, essa tendência convida a refletir sobre o passado. O acervo de lembranças herdado e transmitido por uma geração às seguintes faz do conteúdo simbólico do objeto cultural traço compartilhado pelas memórias pessoal e coletiva.

Inscritos na ideia de tradição e transmissão, afirmou Emmanuel Diet (2010, p. 41), objetos culturais constituem tesouros de significação e matrizes de sentidos, organizadores da relação da pessoa consigo e com os demais, pois induzem configurações do inconsciente, assim como modelos identitários e relacionais dos elementos que presentificam e representam. É próprio do objeto cultural estar nos pensamentos e desejos construídos sobre o fundo originário de uma condição humana que ele traduz e representa de forma socio-histórica. Nesse sentido, a questão da identidade cultural também estaria incluída na forma como o vendedor expressa o pregão, pois, conforme Maria Inez Machado Borges Pinto (1994, p. 161): "Muitos destes vendedores ambulantes de miudezas e petiscos, estrangeiros, serviam-se dos atrativos exercidos pela sua diferença cultural, sobretudo da língua, das canções, usando-as como recursos para atrair a clientela." O vassoureiro que apregoava "Liberté, Egalité, Fraternité, Vassourê!" distinguia-se, não só pela nota de humor no pregão, mas devido ao prestígio do idioma francês nos séculos XIX e XX.

Sobre o uso do idioma francês, comentou Soares (2007, p. 126): "Não eram poucos os vendedores ambulantes que percorriam as ruas da cidade e ainda procuravam tirar vantagem da sua liberdade de locomoção, encarregando-se da entrega de recados, mensagens e cartas de indivíduos livres". O autor menciona um personagem de A Moreninha (1844), Dona Gabriela, "autêntica moça namoradeira" 
que se valia "dos serviços de uma preta vendedora de empadas para levar as cartas que escrevia a seus namorados" (MACEDO, 1967, p. 110 apud SOARES, 2007, p. 126). Soares ratifica o exemplo citando o "Estudo sobre as perversões e inversões do instinto genital", escrito por José Ricardo Pires de Almeida (1843-1913), médico que aludiu à participação dos vendedores ambulantes na "alcovitice tradicional" do Rio de Janeiro. O mais célebre "moleque de recados" local era um jovem Crioulo, conhecido por "Marchand de Fleurs". Aprendera o idioma servindo como copeiro a uma família francesa e "[...] procurava atrair a clientela com altos pregões em francês, o que the valeu o apelido dado pela população" (SOARES, 2007, p. 127). O relato do Doutor Pires de Almeida enriquece a crônica de costumes de uma época:

\begin{abstract}
Ocupava-se em vender, percorrendo as ruas mais frequentadas, ramalhetes de flores que apregoava em altas vozes. Dessa indústria, aparentemente pouco lucrativa, hauria o hábil crioulo todo o partido, servindo a sua mercadoria de cartão para entrada franca em casa de família, onde entregava sorrateiramente perfumadas cartinhas de namoro e bilhetes para entrevistas diurnas e noturnas. (ALMEIDA, 1906, p. 74 apud SOARES, 2007, p. 127).
\end{abstract}

Figura 02: "Vendedor de flores à porta de uma igreja" (1816-1831), de Jean-Baptiste Debret

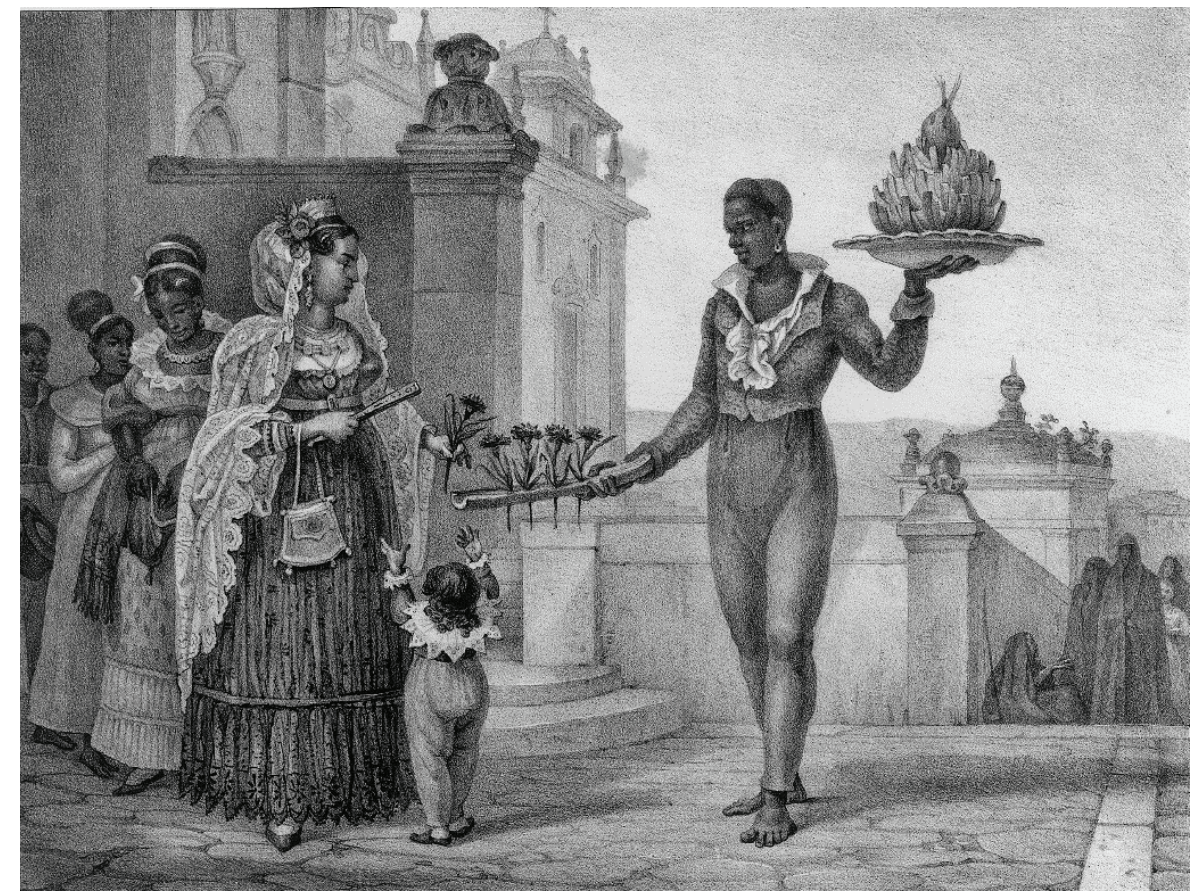

FONTE: Gravura de Viagem Pitoresca e Histórica ao Brasil (1834) ${ }^{3}$

Datadas de 1957, as crônicas de Jorge Americano descrevem o cotidiano das ruas de São Paulo, recordando: "O vaivém da serra manual da serraria do outro quarteirão e o canto da cigarra, o assobio do afiador de facas, uma porção de pregões na rua e o canto da lavadeira batendo a roupa". Desse arquivo sonoro, o memorialista lembra o idioma francês usado pelo vendedor ambulante como atrativo:

3 Imagem retirada pela autora do site Slavery Images. Disponível em: < $\underline{\text { http://slaveryimages.org/s/ }}$ slaveryimages/item/840>. Acesso em: 03 de outubro de 2019. 
Ouve-se um assobio e o pregão: "Amolador!" (...) Ouve-se ao longe um pregão fanhoso que não se entende. Não se percebe ao longe ninguém que tenha aspecto de apregoar qualquer coisa. O som se aproxima: "Empalhador!" "Empalhador!" O homem não se distingue dos outros. Ah! Agora distingue-se. Traz na mão um feixe de palhinha de vime. (...) Ouve-se um grito estridente. Este pregoeiro fala francês: "Fraternité, Égalité, 'vassourité', la facilité de la famille." Não é francês, não sabe francês, mas era o vassoureiro preferido, porque the ensinaram aquelas imbecilidades. (AMERICANO, 2004, p. 105112, grifo do autor).

Em Memória e Sociedade: Lembranças de Velhos, publicado em 1979, Ecléa Bosi reúne vários pregões. O trecho seguinte pertence ao relato do Sr. Antônio, filho de italianos, nascido em uma fazenda, no interior do estado de São Paulo. A família mudou-se para a capital paulista em 1910. Neste depoimento, Ecléa Bosi observou em nota de rodapé ter recolhido o pregão: "Liberté, Egalité, Fraternité, Vassourê!":

O vassoureiro era célebre em São Paulo com seu pregão em francês que não lembro mais. Tinha o pai do Salerno, colega meu do grupo escolar: Outro, que era acendedor de lampiões da Companhia de Gás (naquele tempo São Paulo era iluminada a gás), vendia espigas quentes, e diziam que virava lobisomem: "Ei, espiga cávida!" (...) Cada bairro tinha seus apregoadores. (BOSI, 1995, p. 231).

As memórias pessoais coligidas por Eclea Bosi contribuem significativamente para uma abordagem interdisciplinar do pregão como objeto cultural, ao reunir vários aspectos que o representam, incluindo sua transcrição musical, as localidades onde circulavam os vendedores ambulantes, os produtos anunciados, a forma como eram anunciadas as mercadorias e fragmentos da história e identidade dos ambulantes. A coleção de depoimentos e recordações organizada pela autora oferece vislumbres sobre pregões e vendedores no contexto da vida urbana em princípios do século XX.

Nas sociedades em processo de urbanização dos séculos XIX e XX, pregões e vendedores ambulantes são integrantes de uma economia e de um mecanismo de difusão de informações, a exemplo da participação dos vendedores ambulantes na "alcovitice tradicional" do Rio de Janeiro referido por José Ricardo Pires de Almeida.

\section{Considerações finais}

Eclea Bosi, Jorge Americano, Mário Souto Maior e Luiz Carlos Soares aludem a vendedores ambulante e pregões por descrições extraídas da cultura impressa, da imprensa local, de relatos de viajantes, do depoimento de pessoas comuns e dos escritos dos homens de ciências e letras de uma época. Retratos de escravos de ganho e vendedores ambulantes, a exemplo das gravuras de Jean-Baptiste Debret e Joaquim Lopes de Barros, reproduzem as imagens de "traços" materiais do passado.

Historiadores e cronistas de costumes encerram os pregões e vendedores de rua em diferentes tipos de arquivo, vinculando seu significado (cultural, econômico e social) a certa comunidade, época e região. Pedro Nava referiu vendedores de rua 
e pregões das cidades do Rio de Janeiro e Juiz de Fora, no início do século XX, em descrições esteticamente elaboradas a partir das próprias recordações de infância.

Daniel Kidder, Jean-Baptiste Debret, Joaquim Manuel de Macedo, José Ricardo Pires de Almeida, Maria Inez Machado Borges Pinto, Marlos de Barros Pessoa, Walter Garcia e Thomas Ewbank fornecem, sobre pregões e vendedores de rua, dados que apreendem diferentes instâncias da memória histórica: a exploração da mão de obra escrava; o "grande tato e tino comercial" do escravo de ganho e dos "moleques de recados" de "moças namoradeiras"; as consequências do processo de urbanização e mecanização do trabalho; os artefatos e costumes populares; o som "dos pregões vindos dos velhos tempos coloniais" (FREYRE, 1961, p. 178-181 apud GARCIA, 2013, p. 21) ou o pregão cujos dizeres aludiam à Revolução Francesa.

Pregões e vendedores ambulantes são citados por "traços" que os distinguem como objetos culturais históricos, nostálgicos, pitorescos e singulares, resultantes de maneiras e "artes de fazer" de "vendedores de manuês" e "vendedores de roletes de cana", de "guloseimas"; da musicalidade de "pregões antigos", "bonitos e saudosos"; ou do "grito estridente" do "vassoureiro preferido". Os traços que atribuem sentido de patrimônio imaterial a pregões e vendedores de rua tendem a desaparecer, quando confiados apenas à "memória dos que envelhecem", definida por Pedro Nava (1974, p. 17) como repositório para "[...] a lembrança dos pequenos fatos que tecem a vida de cada indivíduo e do grupo com que ele estabelece contatos, correlações, aproximações, antagonismos, afeições, repulsas e ódios". Nesse sentido, Ecléa Bosi coligiu histórias e "lembranças de velhos" que referem pregões e vendedores de rua.

As descrições de pregões e os retratos de vendedores de rua no Brasil, registrados por cronistas, viajantes, pintores, escritores e memorialistas dos séculos XIX e XX, constituem valiosas fontes de pesquisa. $\mathrm{O}$ registro da maior parte desses pregões poucas vezes é acompanhado de partitura, omitindo vestígios de qualquer traço sonoro de sua música para o pesquisador que analisa textos e imagens. Assim sendo, parte do compósito que o pregão representa usualmente desaparece, ao não ser conservado e transmitido no tempo. A musicalidade, as inflexões da voz, gestual e aparência de quem anuncia o pregão enriquecem a "arte de fazer" que o distingue.

\section{Referências}

AMERICANO, Jorge. São Paulo naquele tempo (1895-19015). São Paulo: Editora Carrenho, 2004.

ASSANO, Christiane Reis Dias Villela. O pregão da Rua de Mata-Cavalos. In: Cadernos do Colóquio. Rio de Janeiro: Editora UNIRIO, v. 6, n. 1, p. 42-48, 2003.

BOSI, Ecléa. Memória e sociedade: lembranças de velhos. São Paulo: Companhia das Letras, 1995. 
BOUSIER, Jean-Yves. La mémoire comme trace des possibles. In: Socioanthropologie. Paris, v. 12, 2002.

CERTEAU, Michel de. A invenção do cotidiano: 1, artes de fazer. Tradução Ephraim Ferreira Alves. Petrópolis: Vozes, 2003.

CERTEAU, Michel de; GIARD, Luce; MAYOL, Pierre. The practice of Everyday Life. Volume 2: Living and Cooking. Translated by Timothy J. Tomasik. Minneapolis: University of Minnesota Press, 1998.

COHEN. Paul. History and Popular Memory: The Power of History in Moments of Crisis. New York: Columbia University Press, 2014.

DEBRET, Jean Baptiste. Viagem pitoresca e histórica ao Brasil (1816-1831). Tradução e notas de Sérgio Milliet. $3^{\mathrm{a}}$ Ed. São Paulo: Livraria Martins, 1954.

DIET, Emmanuel. L'óbjet culturel et ses fonctions médiatrices. In: Connexions. Paris, n. 93, p. 39-60, 2010.

FREYRE, G. Sobrados e Mucambos. Rio de Janeiro: Record, 1996.

GARCIA, Walter. Melancolias, Mercadorias. Cotia, SP: Ateliê Editorial, 2013.

GOSDEN, Chris; MARSHALL, Yvonne. The Cultural Biography of Objects. In: World Archeology. London, v. 31, n. 2, Oct. 1999, p. 169-178, 1999.

GRISWOLD, Wendy. Cultures and Societies in a Changing World. London: Sage, 2013.

HETHERINGTON, Kevin. The Ruin Revisited. In: PYE, Giulian; SCHROTH, Simone (Eds.). Trash Culture: Objects and Obsolence in Cultural Perspective. Oxford: Peter Lang, 2010, p. 15-38.

KARASCH, Mary C. Slave Life in Rio de Janeiro, 1808-1850. Princeton, New Jersey: Princeton University Press, 1987.

KNORR-CETINA, Karin D. The ethnographic study of scientific world: Towards a constructivist interpretation of Science. In: KNORR-CETINA, Karin D.; MULKAY, Michael Joseph (Eds.). Science observed. London: Sage, 1983, p. 115-140.

MAIOR, Mário Souto. Recife: a riqueza de seu folclore. Mario Souto Maior vida \& obra, s/d. Disponível em: http://www.soutomaior.eti.br/index.php?option=com_conten t\&view=article\&id=53\&ltemid=13. Acesso em: 08/10/2019. 
NAVA, Pedro. Balão cativo. Rio de Janeiro: Livraria José Olympio, 1977.

Baú de ossos. Rio de Janeiro: Livraria José Olympio, 1974.

NORA, Pierre. Between Memory and History: Les Liéux de Mémoire. Representations. Paris, n. 26, p. 7-24, 1989.

PESSOA, Marlos de Barros. Formação de uma variedade urbana e semi-oralidade: o caso do Recife, Brasil. Tübingen: Max Niemeyer Verlag, 2003.

PINTO, Maria Inez Machado Borges. Cotidiano e sobrevivência: a vida do trabalhador pobre na cidade de São Paulo, 1890-1914. São Paulo: Edusp, 1994.

PRAGANA, Maria Elisa Collier. Pregões recifenses. In: MAIOR, Mário Souto. Antologia Pernambucana de Folclore. Vol. 2. Recife: Fundação Joaquim Nabuco, Editora Massangana, 1988, p. 125-130.

ROMANO, Luís Antônio Contatori. Debret, Gilberto Freyre, Cecília Meireles: representações do comércio de rua no Brasil e suas influências orientais e africanas. Revista de estúdios brasileños. Salamanca: Ediciones Universidad de Salamanca, v. 7 , n. 14 , p. $35-48,2020$ a.

ROMANO, Luís Antônio Contatori. O olhar do viajante e do turista em representações do comércio de rua no Brasil por Debret, Gilberto Freyre e Cecília Meireles. Dos Algarves: A Multidisciplinar e-Journal. Faro: Editora da Universidade do Algarve, $\mathrm{n}$. 37, p. 1-21, 2020b.

SOARES, Luiz Carlos. O "povo de cam" na capital do Brasil: a escravidão urbana no Rio de Janeiro do Século XIX. Rio de Janeiro: Faperj - 7 Letras, 2007.

WALTY, Ivete Lara Camargos. Jornaux de rue: espaces entrecroisés. In: GIN, Pascal; Moser, Walter (dir.). Mobilités culturelles: regards croisés Brésil/Canadá. Ottawa: Les Presses de l'université d'Ottawa, 2011, p. 79-100.

Recebido em outubro de 2019.

Aprovado para publicação em março de 2021. 